\title{
The drained world
}

\section{Deep thoughts.}

\section{Ian Watson}

The sun beat down on the private beach near Marbella.

"Today the tide seems to have stopped short," said the plutocrat Vasili Romanovitch, consulting his very waterproof Rolex. "Yesterday, the sea reached the top of that little green rock. Now, only the bottom."

A popular fallacy is that the Mediterranean has no tides, being the wrong size to resonate to the attractions of the Moon and Sun. On the other hand: what's wet, and moves up and down a beach significantly twice a day?

"Only the bottom," Vasili repeated, eyeing Jacqueline Johnson as she fastened her bikini top and arose to peer.

"And maybe," she responded, blue eyes gleaming, "this is only the beginning."

Jacqueline's speciality was defying conventional thinking, so she endorsed the opinion of the Spanish and Greeks and other circum-Med nationalities that their shared sea has tides. What's wet, and regularly moves up and down a beach?

"You mean the beginning of global warming evaporation?" asked Andrei, one of Vasili's bodyguards, whose hairy gut hung out over his baggy trunks.

This idiocy didn't really deserve an answer, but she replied calmly: "Of the emptying I predicted as a possibility."

To be fair, Andrei probably mentioned evaporation because more water evaporated from the Med every day than was replaced by all the rivers flowing into it. Hence, constant replacement from the Atlantic Ocean.

Jacqueline fished in her Gucci bag for her multifone and swiftly searched the web. "Of course, oceanic tide levels vary greatly from place to place, but in general it seems the Atlantic is half a metre lower than yesterday." She swiftly calculated the very large volume of sea water that had been lost. "Vasili, we should return to the yacht."

"Before it cannot float?" asked Andrei.

"That will be quite a while yet," snapped Vasili, who understood science, hence his patronage of Jacqueline and her theory that, if true, would require much readjustment worldwide.

"Where can so much sea water go to?" persisted Andrei. "Round the bottom of South America into the Pacific? Would not the planet lean over?"

"Into," said Vasili, "caverns measureless to man." His plutocrat father had sent him to an English public school to be polished, and as a result he could quote Coleridge. "Porous regions deep beneath the ocean floor, which we may well call voids. And which we shall now seriously begin to measure. I shall establish the Romanovitch Foundation, to be headed by Jacqueline. We must try to discover how much ocean will disappear. How the map of the world will be redrawn. I shall need to liquidate assets."

Andrei, who had been in the FSB, still thought of assets as informants, and of liquidation as assassination, and his hand now formed a pistol shape, but Vasili shook his head.

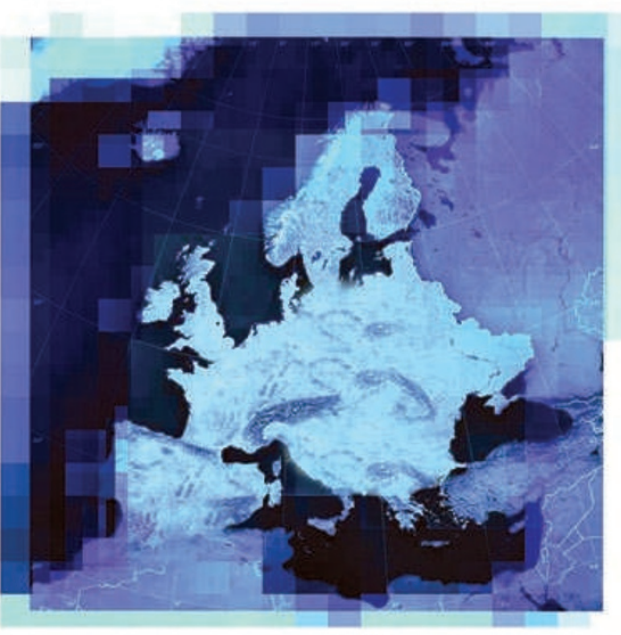

"Our incomplete business with our contacts on this costa is at an end now. Forgive my referring to business matters," he added to Jacqueline, as he wished to keep their scientific relationship unsullied. "We shall set sail. We have other fish to fry."

Jacqueline, and her suspect alliance with the Russian plutocrat, had been vindicated. Even as they cruised through the Strait of Gibraltar, she was studying the latest news and getting ready to address a plenary session of the Intergovernmental Panel on Climate Change by video link. Colder Atlantic surface water constantly flowed into the Med to replenish evaporation minus river input; and warmer Med water flowed out beneath the density boundary at 100 metres. As the greatest depth of the Strait of Gibraltar was 900 metres, the diminished Med would become landlocked in a mere 5 years. Yet, according to Jacqueline's calculations, the rate of oceanic drainage might soon increase to a metre per day, or more.

"As an analogy," Jacqueline was soon telling the video camera, and the IPCC, "imagine enormous two-way trapdoors of stone in the depths of the Atlantic, and doubtless the Pacific too, as well as the Indian Ocean. The extra weight of sea water due to greenhouse melting has opened these gates - they reached the tipping point. Formerly some maverick scientists thought there might be giant oceans beneath the sea floor that pressure of magma might push upward, drowning even Mount Everest. But no, currently there are enormous unsaturated porous regions. The question is: how enormous?"

"Our bathysphere is stuck," Jean-Luc radioed to the surface 18 months later. "The downward suction is too great. Thank God you didn't come this time, Jacqueline. At least we'll have time before our air runs out to determine the size of the void below us."

Three hours later Jacqueline finished calculating how much more of the Atlantic would fill the Jean-Luc Void, as the two-man bathysphere team breathed their last. This volume, plus those of other voids already plumbed, indicated a future worldwide sea level one kilometre below the 2010 mean datum.

"Very acceptable," said Vasili. "So we won't have a desert world with no rainfall, nor any drop to drink except that obtained by a few hundred thousand high-tech survivors pumping water from the underground oceans for desalination to sustain them and their vegetables and chickens and pet cats. This calls for champagne. Andrei, you may splice the main brace and cancel the Arks of Water project. We shall drink to Jean-Luc and Marc-Antoine." Vasili mused. “The Med will be reduced to an Ionian Lake. With no North Sea, Britain becomes part of Europe again. Scandinavia joins the Baltic States. There mightn't be much Caribbean apart from a Cayman Trench Lake. I expect many geopolitical changes."

Two years later, the mass migration from Africa into Europe began. Enough fish trapped in pools sustained the advancing masses until relatively clean nuclear weapons detonated along the bed of the Med as a warning.

With apologies to Stephen Baxter's splendidly disconcerting Flood. Ian Watson is the author of The Embedding, The Martian Inca, Chekhov's Journey and other light classics. Join the discussion of Futures in Nature at go.nature.com/QMAm2a 